https://jurnal.unigal.ac.id/index.php/jall/index

ISSN: 2598-8530

September 2017, Vol. 1 No. 2

English Education Program

Faculty of Teacher Training and Education

Galuh University

\begin{tabular}{|ccc|}
\hline Received: & Accepted: & Published: \\
\hline July 2017 & August 2017 & September 2017 \\
\hline
\end{tabular}

\title{
PERCEPTIONS OF THE NON-ENGLISH DEPARTMENT LECTURERS TOWARDS CLIL IN HIGHER EDUCATION
}

\author{
Fitri Budi Suryani \\ fitri.budi@umk.ac.id \\ Universitas Muria Kudus, Jawa Tengah
}

\begin{abstract}
Content and Language Integrated Learning (CLIL) is an approach to learning activity that uses foreign language as a medium for learning content so that the competence on the language and the subject area content can be achieved simultaneously. CLIL can be implemented in elementary level, secondary level, as well as tertiary or higher education level. In higher education, CLIL might have two significant reasons to be implemented: the globalized world and university internationalization. So far in Indonesia, nearly all universities have not implemented CLIL yet. This study aims at finding out the lecturers' perceptions towards CLIL in higher education. The participants of the study were thirty-three lecturers from non-English departments of Universitas Muria Kudus. The intrument to collect the data was closed-ended questionnaire. The result reveals that the non-English department lecturers quite disagree for CLIL to be implemented in higher education. Their objection for having English as a medium of instruction seems to lie in their own ability of English as well as their students' poor English proficiency.
\end{abstract}

Keywords: CLIL, higher education, non-English department lecturers

\section{INTRODUCTION}

Content and Language Integrated Learning (CLIL) is an approach to learning activity that uses English as a medium for learning content. CLIL can be implemented in elementary level, secondary level, as well as tertiary or higher education level. 
In higher education, CLIL might have two significant reasons to be implemented. First is pertaining to the globalized world. As the rapid changing in the globalized world, more and more university graduates are demanded to master international languages if they are to compete successfully. One of the popular widespread languages used in the world is English. Therefore, the mastery of English by university students in Indonesia will make them not only bilinguals but also multilinguals as many Indonesians have usually mastered at least two languages, i.e. Indonesian and regional language like Javanese, Sundanese, Batakese, etc.

Cook (2002) states that "the advantages that multilinguals exhibit over monolinguals are not restricted to linguistic knowledge only, but extend outside the area of language". Thomas and Collier (1998) note the substantial long-lived cognitive, social, personal, academic, and professional benefits of being multilinguals. This is in line with Hakuta (1986) who specifies the benefit of multilingual as displaying generally greater cognitive flexibility, better problem solving and higher-order thinking skills. All those skills are highly needed for successfully competing in the globalized world.

The second reason deals with university internationalization. The need for universities to be acknowledged internationally has increased the use of English for anything in university everyday life. This might include the use of English for university administration and website, the need of university authorities, lecturers and students to converse in English, and the use of English in teaching learning process not only for English department, but also all departments.

So far in Indonesia, nearly all universities have not implemented CLIL yet. Nevertheless, this actually does not depict the reluctance or absence of interest from the university authorities, lecturers and students on having CLIL. As the demand of university graduates contributing in the globalized world and internationalization of university urges, the idea of implementing CLIL in higher education becomes an obvious important issue to consider.

This study aims at finding out the lecturers' perceptions towards CLIL in higher education. Having the lecturers' perceptions towards CLIL in higher education is significant because the lecturers will be the ones who will greatly involve in implementing CLIL if one day it is decided to be applied. Those lecturers will be the main actors/actresses as they will teach the subject content using English as a medium of instruction to their students. 


\section{Bilingualism and Multilingualism}

Bhatia and Ritchie (2013) suggest that the term bilingualism and multilingualism are replaced with the term pluralingualism to refer to the knowledge and use of two or more languages rather than repeating the term bilingualism and multilingualism over and over again. Despite the practical consideration of the term pluralingualism, the fact shows that pluralingualism, either bilingualism or multilingualism, is found worlwide nowadays. As Crystal (in Bhatia and Ritchie, 2013) reported, over $41 \%$ people in the world are pluralinguals. And it seems that the number will keep increasing along with the globalization.

Pluralingualism arise because of some situations and circumstances. Among those, Edwards (2013) mentions immigrants, political union, and cultural and educational motivations. Through immigrants, new language is introduced through military, religious, or economic force that involve only small numbers of soldiers, merchants, bureaucrats, and missionaires.

Pluralingualism can also arise due to the result of political union between countries with different languages. Edwards (2013) gives examples of Switzerland incorporating German, Italian, Romansch, and French populations; Belgium uniting French and Flemish.

Cultural and educational motivations are other circumstances that create pluralingualism. This can occur individually or collectively. The cultural and educational motivations that occur collectively might be the fertile conditions for CLIL to grow in many countries around the world.

\section{CLIL}

CLIL is a pedagogic approach that combines language and subject area content to be learnt (Coyle et al, 2009). In other words, a foreign language is used to learn a subject area content so that the competence on the language and the subject area content can be achieved simultaneously. As Coyle et al (2009) assert, "learners process and use language to acquire new knowledge and skills and as they do so they make progress in both language and subject area content".

Beginning to be popular in Europe in 2003, CLIL receives special attention as one of the ways to achieve the objective of learning two languages in addition to the mother tongue. This is due to the language context in Europe that is multilingual. Furthermore, the European langugae policies support the promotion and implementation of multilingualism. 
Thus, there is no wonder that CLIL can develop and reach success in Europe as most countries in Europe have initiated CLIL-based programs.

Van de Craen et al. (2007) mention four main aims of CLIL. They are (i) the promotion of linguistic diversity; (ii) promoting language learning; (iii) increasing the learner's proficiency; and (iv) internationalization.

CLIL has the benefit, according to Ioannou-Georgiou and Pavlou (2011), not only to imrpove language skills and subject knowledge, but also to develop intercultural knowledge and understanding as well as intercultural communication skills of the learners. Furthermore, Ioannou-Georgiou and Pavlou (2011) note that CLIL 'promotes the development of diverse learning strategies, the application of innovative teaching methods and techniques and the increase of learner motivation'.

CLIL can be implemented in any language, at any age, as well as at any level of education ranging from elementary, secondary, and tertiary education. Therefore, the model of CLIL varies depending on those things. Ioannou-Georgiou and Pavlou (2011) propose CLIL varieties that include different kinds of immersion, subject courses, exposure to CLIL language for pre-primary and primary education, and language classes based on thematic units.

The kinds of immersion lie from partial to total immersion and depend on how intense the exposure given and how long the teaching learning process occured. Meanhwile, the subject courses taught may vary from citizenship, environmental studies, etc. For pre-primary and early years of primary level of education, the language exposure is regular, short, and continuous in one subject area and given for around 15 to 30 minutes several times per week. The language classes take thematic units-based with emphasis on content. Thus, Ioannou-Georgiou and Pavlou (2011) suggest that their 'syllabus and lesson plans involve a topic-based approach including specific themes or content to be dealt with in the language lesson'.

\section{METHOD}

This study objective is to investigate the lecturers' perceptions towards CLIL in higher education. The subjects of this study were the lecturers of Universitas Muria Kudus from the non-English Departments. Those non-English Departments included Guidance and Counseling, Elementary School Teacher Education, Law, Economic, Psychology, Farming, and Engineering. The choice of lecturers from the non-English departments only is based on consideration that the non-English Departments lecturers are the agents who 
will implement CLIL in their classes. Hence, it is utmost necessary to delve into their CLIL perceptions.

The number of the lecturers contributing in this study was 33. The following table presents the number of the lecturers in detail from each department.

Table 1. The Number of Lecturers in the Study

\begin{tabular}{lc}
\hline \multicolumn{1}{c}{ Department } & $\begin{array}{c}\text { The Number of } \\
\text { Lecturers }\end{array}$ \\
\hline Guidance and Counseling & 2 \\
\hline Elementary School Teacher Education & 6 \\
\hline Law & 1 \\
\hline Psychology & 4 \\
\hline Farming & 2 \\
\hline Economic & 7 \\
\hline Engineering & 11 \\
\hline
\end{tabular}

The instrument used to collect the data in this study was questionnaire. The questionnaire was adapted from Kilickaya (2000) who adapted from Tung, Lam, and Tsang (1997) with minor modifications. Since not all subjects understand English, the questionnaire was translated into Indonesian with few changes needed.

The questionnaires were close ended ones and had a twenty-three Likert scale items. There were five optional answers that must be chosen by the lecturers, i.e. never, sometimes, half the time, frequently, and always.

The data from the closed-ended questionnaires were analysed quantitatively by calculating the mean of every item in the questionnaire. The result was then interpreted qualitatively to capture the perceptions of the non-English department lecturers towards CLIL in higher education.

\section{FINDINGS AND DISCUSSION}

The findings of the study summarized from the questionnaires given to the nonEnglish department lecturers can be seen in the following table 2. 
Table 2. The Analysis of the Closed-Ended Questionnaires

\begin{tabular}{|c|c|c|}
\hline No & Questionnaire Items & Mean \\
\hline 1 & $\begin{array}{l}\text { Lecturing in Indonesian can bolster students' interest in learning } \\
\text { more than lecturing in English. }\end{array}$ & 3.67 \\
\hline 2 & $\begin{array}{l}\text { Lecturing in Indonesian allows the lesson to progress faster than } \\
\text { lecturing in English. }\end{array}$ & 4.06 \\
\hline 3 & $\begin{array}{l}\text { Lecturing in Indonesian produces a better classroom atmosphere } \\
\text { than lecturing in English. }\end{array}$ & 3.76 \\
\hline 4 & $\begin{array}{l}\text { Lecturing in Indonesian allows a teacher to go deeper into the } \\
\text { content of the lesson than lecturing in English. }\end{array}$ & 3.73 \\
\hline 5 & $\begin{array}{l}\text { I support adopting mother-tongue education at the university } \\
\text { where I teach. }\end{array}$ & 3.76 \\
\hline 6 & $\begin{array}{l}\text { I feel it is easier to set examination questions using English than } \\
\text { using Indonesian. }\end{array}$ & 2.18 \\
\hline 7 & I feel I can write better in English than in Indonesian. & 2.21 \\
\hline 8 & $\begin{array}{l}\text { The greatest problem in using Indonesian as the medium of } \\
\text { instruction is the need to translate a lot of special terms. }\end{array}$ & 3.36 \\
\hline 9 & $\begin{array}{l}\text { It is easier to teach non-language subjects (e.g., Guidance and } \\
\text { Counseling, Law, Engineering) in English than in Indonesian. }\end{array}$ & 2.3 \\
\hline 10 & $\begin{array}{l}\text { Resources for teaching, e.g., textbooks and reference books, are } \\
\text { more plentiful in English than in Indonesian. }\end{array}$ & 3.12 \\
\hline 11 & $\begin{array}{l}\text { The Teacher Training and Education Faculty should provide } \\
\text { universities that adopt mother-tongue education with more } \\
\text { resources for teaching. }\end{array}$ & 3.18 \\
\hline 12 & $\begin{array}{l}\text { The Indonesian government should raise the status of the } \\
\text { Indonesian language in society. }\end{array}$ & 4.06 \\
\hline 13 & Learning Indonesian well will benefit the learning of English. & 3.67 \\
\hline 14 & $\begin{array}{l}\text { English as the medium of instruction will certainly lead to } \\
\text { poorer student intake. }\end{array}$ & 3.12 \\
\hline 15 & $\begin{array}{l}\text { Parents are the major obstacle in the promotion of mother- } \\
\text { tongue education. }\end{array}$ & 1.64 \\
\hline 16 & glect those subjects taught in Indo & 1 . \\
\hline
\end{tabular}




\begin{tabular}{|c|c|c|}
\hline 17 & $\begin{array}{l}\text { Teaching a class in Indonesian encourages students to speak } \\
\text { uninhibitedly, thereby disrupting the order of the class. }\end{array}$ & 2.21 \\
\hline 18 & $\begin{array}{l}\text { Even studying every subject in Indonesian will not help students } \\
\text { with poor academic performance. }\end{array}$ & 2.67 \\
\hline 19 & $\begin{array}{l}\text { Using Indonesian to study non-language subjects (e.g., } \\
\text { Guidance and Counseling, Law, Engineering) will affect } \\
\text { students' English proficiency. }\end{array}$ & 2.94 \\
\hline 20 & $\begin{array}{l}\text { Students with good academic performance should study all } \\
\text { subjects in English. }\end{array}$ & 3.15 \\
\hline 21 & $\begin{array}{l}\text { The English proficiency of the students I teach is not adequate } \\
\text { for them to study non-language subjects (e.g., Guidance and } \\
\text { Counseling, Law, Engineering) in English. }\end{array}$ & 3.73 \\
\hline 22 & $\begin{array}{l}\text { I have a good understanding of the language policy of the } \\
\text { university where I teach. }\end{array}$ & 3.85 \\
\hline 23 & $\begin{array}{l}\text { It is inappropriate for lecturers to teach the same lesson mixing } \\
\text { English and Indonesian. }\end{array}$ & 2.18 \\
\hline
\end{tabular}

Based on the table above, most of the non-English departments lecturers view Indonesian as a better language tool than English as revealed in questionnaire items $1-5$. They perceive that by using Indonesian, they can make their students to learn better than by using English. This is because they can go deeper into the content of the lesson by using Indonesian. In addition, the use of Indonesian enables the development of better classroom atmosphere. As a result, their students will achieve the lesson goal better. Thus, they support if Indonesian is used as a medium of instruction in tertiary level. Only very few who agree to have English as a medium of instruction.

The similar perception of many non-English lecturers is also performed through their attitude on their English written ability in which most of them found difficulty to make questions and write in English. They perceive that using English to teach their subjects is more difficult than using Indonesian. However, they admit that a lot number of resources are more available in English.

Most of those lecturers also agree that the status of Indonesian should be raised by the government and facilitated by the university. They even believe that parents support 
their view too. They are quite confident that they have good understanding of the language policy in their university.

The use of Indonesian in teaching learning process, as perceived by many lecturers, is not the cause of their students' neglecting their subjects or uncontrolling class situation. Unfortunately, the lecturers seem to doubt that using Indonesian can help their students with poor academic performance to reach better performance although they seem to be sure that the use of English to teach will lead to poorer student intake. In this case, the lecturers confirm that the problem of the poor students' academic performance should be solved by other solutions other than language.

Most of them also perceive that learning Indonesian will benefit the learning of English. However, they do not see that by using Indonesian, the students' English proficiency will be affected. Even so, most of them do not mind in mixing the Indonesian and English during the teaching learning process.

Dealing with the students' English proficiency, many lecturers agree that their students have inadequate English proficiency to study non-language subjects. This seems to be the one of the causes for their objection in using English as a medium of instruction. For the students with good academic performance, they also do not recommend them to study the subjects in English.

It can be inferred then that most of the non-English department lecturers prefer to have Indonesian as a medium of instruction than English. This seems to be in contrast with the university spirit for their graduates to be able to contribute in the globalized world and accepted in the world market. The use of Indonesian in one side will surely raise the status of Indonesian. But without the use of English to teach the non-language subjects, the students will not get adequate exposure to English that might affect their English proficiency. As a result, they will not be able to compete in the global market.

Moreover, Universitas Muria Kudus has set plan and program to be internationally acknowledged. This internationalisation university agenda will not be able to run well if the lecturers as the agents of teaching learning process do not give support for the use of English in their non-subjects classes. Apart from the constraints in having CLIL in higher education, the perceptions of the non-English lecturers will surely influence the direction of CLIL in Universitas Muria Kudus. 


\section{CONCLUSIONS}

The study concludes that the non-English department lecturers of Universitas Muria Kudus are more favourable to use Indonesian as the medium of instruction for the non-language subjects in their classes. They perceive some benefits of using Indonesian to teach, i.e. their students can have better and faster understanding on the subject, show acceptable behaviour, achieve the lesson goal, and create better classroom atmosphere.

Therefore, the non-English department lecturers quite disagree for CLIL to be implemented in higher education. Their objection for having English as a medium of instruction seems to lie in their own ability of English as well as their students' poor English proficiency.

Although the perceptions of the non-English department lecturers are not in line with the university agenda on internationalisation university and seem not to support the idea of promoting their students' proficiency on international language (English), their perceptions are worth considered in determining the direction of CLIL policy in higher education. Thus, the suggestion made for further researcher is to dive deeper on the lecturers constraints of having CLIL on higher education.

\section{REFERENCES}

Bhatia, Tej K and William C. Ritchie. (2013). The handbook of bilingualism and multilingualism. West Sussex: Blackwell.

Cook, Vivian J. (2002). Portraits of the L2 user. Clevedon: Multilingual Matters.

Coyle, Do, Bernadette Holmes, and Lid King. (2009). Towards an integrated curriculumCLIL national statement and guidelines. The Languages Company.

Edwards, John. (2013). Bilingualism and multilingualism: Some central concepts. In Tej K Bhatia and William C. Ritchie (Eds). The Handbook of Bilingualism and Multilingualism. West Sussex: Blackwell.

Ioannou-Georgiou, Sophie and Pavlos Pavlou. (2011). Guidelines for CLIL implementation in primary and pre-primary education. Retrieved April 5th 2014 from

www.schools.ac.cy/klimakio/Themata/Anglika/teaching/clil/guidelinesforclilimpl ementation1.pdf.

Hakuta, Kenji. (1986). Cognitive development of bilingual children. Retrieved April 5th 2014 from www.stanford.edu/-hakuta/Publications/(1986). 
Kilickaya, Ferit. (2000). Instructors' attitudes towards English-medium instruction in Turkey. Retrieved April 5th 2014 from www.hltmag.co.uk/nov06/mart01.htm.

Thomas, W.P. and V.P. Collier. (1998). Two languages are better than one. Educational Leadership, 55 (4), 23-26.

Van de Craen, Pit et al. (2007). Why and how CLIL works: An outline for a CLIL theory. Vienna English Working Papers, 6(3), 70-78. 